\title{
Investigating the Relationship Between Perceived Stress and Leisure Coping Strategies among University Students: Eskişehir Technical University Case
}

\author{
Hüseyin Çevik ${ }^{1}$ \\ ${ }^{1}$ Department of Recreation, Faculty of Sport Sciences, Eskişehir Technical University, Eskişehir, Turkey \\ Correspondence: Hüseyin Çevik, Faculty of Sport Sciences, Eskişehir Teknik Üniversitesi İki Eylül Kampüsü \\ 26555 Tepebaşı, Eskişehir, Turkey.
}

Received: January 30, 2020

Accepted: March 20, 2020

Online Published: May 27, 2020

doi:10.5539/ies.v13n6p67

URL: https://doi.org/10.5539/ies.v13n6p67

\begin{abstract}
The problems university students face during their education life often lead to undesirable situations as stress resources. Thus, various methods, techniques and strategies are employed in order to avoid negative effects of stress in their lives. Leisure is one of the effective methods in coping with stress, and leisure coping strategies are "leisure companionship", "leisure palliative coping" and "leisure mood enhancement". However, there are few studies in the literature focusing on the relationship between these strategies and perceived stress. Exploring this relationship is believed to provide valuable insights for university administrations so that they might offer effective recreation programs for their students. Therefore, this study aims to examine the relationship between perceived stress and leisure coping strategies. In addition, it examines whether there is a difference in perceived stress and strategies according to time spent for leisure activities and type of leisure participation. The participants of the study are 338 students, who were determined by using convenience sampling method. The data were collected through a survey that consists of three parts. The first part includes Perceived Stress Scale (PSS), the second one Leisure Coping Strategies Scale (LCSS) and the third one demographic questions about the participants. The data were analyzed by using Pearson Moment-Product correlation, t-test and ANOVA analyses. According to the findings, there is a negative significant relationship between perceived stress level, leisure coping strategies and its subdimensions. The study also found that perceived stress level of the participants who prefer passive participation in leisure activities is significantly different from that of those who prefer active participation. Similarly, the participants who prefer passive participation in leisure activities is significantly different from those who prefer active participation in terms of leisure coping strategies. In conclusion, the study contributes to the literature with these valuable findings and provides important insights for university campus recreation programs and services.
\end{abstract}

Keywords: leisure, leisure coping, perceived stress

\section{Introduction}

During their education, university students encounter various problems that might challenge their "problem-solving" skills and capacities (Çakmak \& Hevdanl1, 2005). Adapting to a new environment, the need to satisfy academic career expectations, problematic social relationships, hunting for job opportunities (Avşaroğlu \& Üre, 2007), leaving family for education, undesirable accommodation conditions, financial problems, career concerns, problems in the department attended and safety problems are among the main stress sources for university students (Savc1 \& Aysan, 2014). Stress level experienced by university students may lead to negative consequences depending on their personality traits and life-styles. When coped with appropriately, stress can energize students and form a basis for desirable future conditions (Doğan \& Eser, 2013).

Individuals employ various coping strategies so that stressful situations may not lead to undesirable consequences (Akbaş, 2018). These coping strategies are examined in two main categories: problem-focused strategies and emotion-focused strategies (Carver \& Scheier, 1994). Problem-focused strategies include activities aiming to eliminate threats or reduce their effects (Türküm, 2002). Those who prefer this type of strategies tend to take tangible actions to change a stressful situation, to deal with the problem directly, to define clearly the problem regarding stress source, to implement alternative actions and to act mindfully (Avşaroğlu \& Üre, 2007). Individuals who use emotion-focused strategies tend to minimize stress-related negative emotions. Instead of 
trying to cope with stress-causing stimulus, these people are involved in activities to reduce the effect of this stimulus such as denying and avoiding the problem and sharing negative emotions with people around them (Türküm, 2002).

Other techniques to cope with stress are as follows: meditation, relaxation techniques involving breathing exercises and imagination, a balanced and healthy diet, improving problem solving skills, planning alternative actions, effective communication, self-control and effective time management (Aydın \& İmamoğlu 2001). In addition, leisure activities are one of the methods that are effective in coping with stress and increasing well-being (Iwasaki \& Mannel, 2000). The studies show that taking up various leisure activities (Patterson and Coleman, 1996), participating in physical activities (Kimball \& Freysinger, 2003) as well as outdoor leisure activities that provide opportunities for people to socialize (Joudrey \& Wallance, 2009) are quite influential while trying to cope with stress. Jordan (2014) suggests that leisure activities are the key factor in attempts to cope with stress.

Although the relationship between perceived stress level and coping strategies was examined in some studies conducted with university students (Kausar, 2010; Shaikh et al., 2004), the relationship between perceived stress and leisure coping strategies has been investigated in a very limited number of studies (Jordan, 2014). In order to better understand the role of leisure in coping with stress, more research is needed on the relationship between perceived stress and leisure coping strategies. Thus, focusing on this issue is likely to bring valuable contributions to the related literature. Universities provide psychological counselling services for their students to help them cope with stress and other similar problems (Şensoy et.al, 2018). In addition, leisure opportunities offered as part of campus recreation programs and services are a method used to cope with stress (Kanters, 2000). Thus, knowledge regarding the relationship between perceived stress level and leisure coping strategies might provide valuable insights for university adminisrations to improve their campus recreation programs and services so that they can be more effective and more precise in achieving predetermined objectives. Therefore, this study aims to examine the relationship between university students' perceived stress level and leisure coping strategies. The following research questions will be answered in the current study:

1) What are perceived stress levels of university students?

2) Which leisure coping strategy do university students use the most while coping with stress?

3) What is the relationship between university students' perceived stress level and leisure coping strategies?

4) Does stress level and leisure coping strategies differ according to the type of leisure activities and duration of these activities?

\subsection{Perceived Stress}

Stress has been an important part of daily life in today's world and has considerable effects on every aspect of human life (Eskin, Harlak, Demirkıran, \& Dereboy, 2013). In a broad sense, stress is defined as an inner reaction by an individual to a threat or pressure against his hysical and psychological limits or pressure and mental tension he feels due to undesirable conditions in a physical and social environment (Güçlü, 2001). According to Hellriegel et al. (1992), stress is a reaction to physical and psychological strain due to an action or state.

Individuals suffer from perceived stress when they consider a stressful situation threatening and complicated and they do not have necessary skills and strategies to solve this specific problem (Cohen, Kamarck, \& Mermelstein, 1983). High levels of perceived stress may result in serious problems such as depression, anxiety and burn-out levels, and its presence might decrease life quality (Diehr et al., 2006; Heinen, 2017) and subjective well-being (Denovan \& Macaskill, 2016). In addition, it might be the reason of certain problems such as bad temper, desperation, anxiety (Saeed et al., 2016), emergence of negative emotions and suicidal ideation (Anastasiades, Kapoor, Wootten, \& Lamis, 2017), drug use (McHugh, Sugarman, Meyer, Fitzmaurice, \& Greenfield, et al., 2020) and bruxism (Cavallo, Carpinelli, \& Savarese, 2016). Finally, many problems specific to university education such as transition from teenage period to young adulthood, heavy academic workload, academic failure, leaving home for education and changing social environment considerably affect university students' stress levels (Borjalilu, Mohammadi, \& Mojtahedzadeh, 2015). Thus, leisure activities can provide numerous benefits for university students if they want to avoid such stress-related problems.

\subsection{The Relationship Between Stress and Leisure}

Individuals' experiences in enjoyable activities play a significant role while they are trying to cope with stress (Folkman, Moskowitz, Ozer, \& Park, 1997). Enjoying leisure activities and participating in enjoyable activities are the key factors in "increased participation" (Şimşek \& Çevik, 2020). Therefore, leisure activities can play important roles in coping with stress since they are often enjoyable experiences. The literature includes many studies supporting the claim that leisure activities have a significant role in coping with stress. Reich and Zautra 
(1981), in their studies conducted with university students, found that leisure and regular participation in enjoyable activities correlate with low levels of stress. Similarly, the study carried out by Iwasaki (2001) revealed that leisure is the key factor in coping with stress. Another study conducted by the same researcher with university students found that leisure coping has both short-term and long-term effects on students (Iwasaki, 2003). Finally, Dewe and Trenberth (2005) conducted a study in New Zealand with secondary school students and suggested that leisure is an important factor in coping with work related stress. In short, the research findings support the claim that leisure plays a significant role in coping with stress. In addition, it is clear that there is a negative correlation between the two structures.

\subsection{Leisure Coping Strategies}

Leisure is considered a buffer against stress to help people stay healthy (Iwasaki, 2001). In other words, it is a method used to cope with stress. For instance, leisure activities can turn into activities to relax people's minds and avoid stress at the end of a difficult day (e.g listening to relaxing music). In addition, people can enjoy their time by benefiting from social support through leisure companionship. Bad psychological mood and emotions due to an argument with a friend can trigger leisure activities to change this negative mood (to reduce negative mood or enhance a positive mood) (Iwasaki \& Mannell, 2000). Iwasaki and Mannell (2000) also emphasize leisure as an effective method in coping with stress and define three strategies as follows: leisure palliative coping, leisure companionship, leisure mood enhancement. Leisure palliative coping sees stress as a time-off to bring people together so that they recharge their batteries and cope with problems more effectively. Leisure companionship concept suggests that people share their volunteer and enjoyable experiences with others as a form of social support. Finally, leisure mood enhancement regulates people's emotions and moods, helps them avoid negative mood and enhances positive mood (Iwasaki, 2003).

\section{Method}

\subsection{Research Model}

The study uses correlational survey model, which aims to determine whether there is a correlation between dependent and independent variables and to find out the degree of this correlation, if applicable.

\subsection{Participants and Procedures}

The population of the study is university students. Due to time, cost, and manageability constraints, the study was conducted with a sampling chosen from this population. Thus, 338 students attending Eskişehir Technical University, who were determined by using convenience-sampling method, participated in the study. The research data were collected on a voluntary basis from the students attending various faculties and vocational schools in Eskişehir Technical University during 2019-2020 academic year. The faculties and vocational schools offering educational services at Eskişehir Technical University are as follows: Faculty of Science, Faculty of Aeronautics and Astronautics, Faculty of Architecture and Design, Faculty of Engineering, Faculty of Sport Sciences, Porsuk Vocational School and Vocational School of Transportation. Total number of students attending the university is 9678 (Eskişehir Technical University, 2020).

$38.5 \%$ of the participants $(\mathrm{n}=151)$ are female and $61.5 \%(\mathrm{n}=241)$ male. As for the Faculty/School they attend, 25\% $(\mathrm{n}=98)$ attend Engineering Faculty, 24\% ( $\mathrm{n}=94)$ Porsuk Vocational School, 19.4\% ( $\mathrm{n}=76)$ Faculty of Sports Sciences, $17.3 \%(\mathrm{n}=68)$ and Faculty of Science and 14.3\% $(\mathrm{n}=56)$ Faculty of Aeronautics and Astronautics. 44.6\% of the participants $(n=175)$ are $1^{\text {st }}$ year students, $30.6 \%(n=120) 2^{\text {nd }}$ year, $11.2 \%(n=44) 3^{\text {rd }}$ year and $13.5 \%(n=53)$ $4^{\text {th }}$ year students and higher. The distribution of the participants according to family income level is as follows: $49.2 \%(n=193)$ less than 4000 TL, 32.1\% ( $n=126)$ between 4001 and 8000 TL, 18.6\% $(n=73)$ between 8001 and 12500 TL. In addition, $33.7 \%$ of the participants ( $\mathrm{n}=132)$ spend $1-10$ hours in a week on leisure activities, $24.2 \%$ $(\mathrm{n}=95)$ 21-35 hours, $22.2 \%(\mathrm{n}=87) \quad 11-20$ hours and 19.9\% $(\mathrm{n}=78) 36$ hours. Finally, $62 \%$ of the participants $(\mathrm{n}=243)$ prefer passive leisure activities and $38 \%(\mathrm{n}=149)$ active leisure activities.

\subsection{Instruments}

The data were collected through a survey, which consists of three parts. The first part includes Perceived Stress Scale (PSS), which was developed by Cohen, Kamarck and Mermelstein (1983) and adapted to Turkish by Eskin et.al (2013). This scale has 5-point Likert format (0-never-4-very often), and items 4, 5, 7, and 8 are reversely scored. Perceived stress level is measured by calculating the points given to each item. An individual score to be obtained from the scale ranges between 0 and 40; 0-13 indicating low perceived stress; 14-26 moderate perceived stress and 27-40 high perceived stress. The second part of the survey consists of Leisure Coping Strategy Scale (LCSS), which was developed by Iwasaki and Mannell (2000) and adapted to Turkish by Çevik, Özcan, and Munusturlar (2018). The scale has 7-point Likert format (1- I totally disagree - 7 - I totally agree). Finally, the third 
section includes questions aiming to collect demographic data about the participants (gender, faculty/school, class level, family income, duration of weekly leisure, types of leisure participation).

\subsection{Data Analyses}

Before the analysis, items 4, 5, 7, and 8-the reversely scored itemsin Perceived Stress Scale (PSS) were recoded accordingly. The collected data were interpreted based on skewness-kurtosis values, Confirmatory Factor Analysis (CFA) for validity, and Cronbach's Alpha coefficient for reliability. In addition, the following analyses were used for different purposes: descriptive statistics; Pearson product-moment correlation coefficient in order to determine the relationship between two variables; t-test in order to compare two groups; and ANOVA analyses in order to compare more than two groups. The equality of group variances was checked by using Levene Test. When the assumption that group variances are equal was confirmed, Bonferroni test, which is a Post-Hoc test, was used to determine the source of this variance. When the variances were not equal, Tamhane's T2 was used accordingly.

Whether the data display normal distribution or not was determined according to the kurtosis and skewness values. The kurtosis value varies between -932 and +332 , and the skew value between -956 and +293 . Since this result is below the \pm 2 thresholds, it can be stated that the data shows the normal distribution (Field, 2000). Since the data showed normal distribution, validity was tested through DFA. The chi-square (x2), chi-square by degrees of freedom values (x2/df), Root Mean Square Error of Approximation (RMSEA) and Standardized Root Mean Square Residual (SRMR), Comparative Fit Index (CFI) and Tucker-Lewis Index (TLI) were used for data and measurement model fit. Chi-square by degrees of freedom values for acceptable level should be less than 3.0 (Kline, 2011), CFI and TLI indexes should exceed 90 (Browne \& Cudeck, 1993), RMSEA values should be equal or less than .08, and SRMR should be less than .05 for acceptable fit (Hair, Black, Babin, \& Anderson, 2014). The fit indices obtained from the analysis support the validity of the measurement $(\mathrm{x} 2 / \mathrm{df}=2.279$, RMSEA $=0.062$, $\mathrm{SRMR}=0.05, \mathrm{CFI}=0.921, \mathrm{TLI}=0.911$ ). Cronbach's alpha (a) coefficient of each scale was calculated for reliability. The reliability coefficient of PSS is 0.789 and LCSS is 0.939 . As these values are greater than 0.70 thresholds according to Nunnaly and Bernstein (1994), it can be stated that the measurement has high reliability.

\section{Results}

For the purposes of the study, the perceived stress levels of the students were measured first (see, Table 1). Later, descriptive statistics for leisure coping strategies were calculated (see Table 2). Next, the relationship between perceived stress level and leisure coping strategies was analyzed (see Table 3). Finally, the researcher wanted to find out whether there is a difference between perceived stress level and leisure coping strategies in terms of the variables "time spent for leisure activities" and "type of leisure participation" (see Table 4-5).

Table 1. Findings related to students' stress level

\begin{tabular}{ccc}
\hline Stress level & $\mathrm{n}$ & $\%$ \\
\hline High stress & 96 & 28.4 \\
Moderate stress & 198 & 58.6 \\
Low stress & 44 & 13.0 \\
Total & 338 & 100 \\
\hline
\end{tabular}

Table 1 shows that $58.6 \%$ of the students experience moderate level of stress. The percentage of students with high level of stress is $28.4 \%$ and with low level of stress $13 \%$. Accordingly, we can say that majority of students have moderate or high levels of stress.

Table 2. Descriptive statistics of students' leisure coping strategies

\begin{tabular}{ccc}
\hline Leisure coping strategies & Mean & Sd. \\
\hline Leisure companionship & 26.40 & 6.88 \\
Leisure palliative coping & 30.63 & 7.43 \\
Leisure mood enhancement & 21.38 & 5.59 \\
\hline
\end{tabular}

According to Table 2, the mean score for "leisure palliative coping"- one of leisure coping strategies- is higher than "leisure companionship" and "leisure mood enhancement" strategies. This finding suggests that the students employ "leisure palliative coping" strategy the most and "leisure mood enhancement" strategy the least while trying to cope with stress. 
Table 3. The correlation between perceived stress and leisure coping strategies

\begin{tabular}{ccccc}
\hline & Leisure coping strategies & Leisure companionship & Leisure palliative coping & Leisure mood enhancement \\
\hline Perceived stress & $-174^{* *}$ & $-154^{* *}$ & $-131^{*}$ & $-190^{* *}$ \\
\hline
\end{tabular}

If we look at Table 3, we can see that Pearson Correlation Analysis, which was done to see whether there is a relationship between the students' perceived stress and leisure coping strategies, shows a negative significant relationship between these two variables $(\mathrm{r}=-174, \mathrm{p}<0.01)$. Finally, the study found negative significant relationships between Perceived Stress Scale (PSS) and the following dimensions of Leisure Coping Strategies Scale (LCS): "leisure companionship" $(\mathrm{r}=-154, \mathrm{p}<0.01 \mathrm{~S})$, "leisure palliative coping" $(\mathrm{r}=131, \mathrm{p}<0.05)$ and "leisure mood enhancement" $(\mathrm{r}=-190, \mathrm{p}<0.01)$.

Table 4. Comparing leisure coping strategies according to perceived stress level

\begin{tabular}{ccccccc}
\hline Leisure coping strategies & Perceived stress & $\mathrm{n}$ & Mean & Sd. & $\mathrm{F}$ & $\mathrm{p}$ \\
\hline \multirow{2}{*}{ Leisure companionship } & Low & 44 & 5.7045 & 1.17373 & & \\
& Moderate & 198 & 5.3458 & 1.24444 & 5.122 & $0.006^{* *}$ \\
& High & 96 & 4.9547 & 1.63913 & & \\
\hline \multirow{2}{*}{ Leisure palliative coping } & Low & 44 & 5.3258 & 1.12291 & & \\
& Moderate & 198 & 5.1615 & 1.17020 & 2.335 & 0.980 \\
& High & 96 & 4.8925 & 1.39923 & & \\
\hline \multirow{2}{*}{ Leisure mood enhancement } & Low & 44 & 5.7045 & 1.12098 & & \\
& Moderate & 198 & 5.4404 & 1.32998 & 5.197 & $0.006^{* *}$ \\
& High & 96 & 4.9861 & 1.58114 & & \\
\hline
\end{tabular}

$* \mathrm{p}<0.05, * * \mathrm{p}<0 . \overline{01}$

When it was examined whether there was a difference between leisure coping strategies and perceived stress level, it was found that there are significant differences in "leisure companionship" $(F=5.122, p<0.01)$ and "leisure mood enhancement" $(\mathrm{F}=5.197, \mathrm{p}<0.01)$ dimensions. In addition, we can see that low perceived stress level significantly correlates with the mean scores of "leisure companionship" $(\mathrm{X}=5.7045)$ and "leisure mood enhancement" $(\mathrm{X}=5.7045)$.

Table 5. Comparison of leisure coping strategies and perceived stress according to weekly time for leisure

\begin{tabular}{|c|c|c|c|c|c|c|}
\hline Leisure coping strategies & Weekly time for Leisure & $\mathrm{n}$ & Mean & $\mathrm{Sd}$. & $\mathrm{F}$ & $\mathrm{p}$ \\
\hline \multirow{4}{*}{ Leisure companionship } & $1-10$ hours & 110 & 5.1586 & 1.42331 & \multirow{4}{*}{0.877} & \multirow{4}{*}{0.453} \\
\hline & 11-20 hours & 78 & 5.3897 & 1.34643 & & \\
\hline & 21-35 hours & 78 & 5.1975 & 1.39095 & & \\
\hline & 36 hours and more & 72 & 5.4425 & 1.32226 & & \\
\hline \multirow{4}{*}{ Leisure palliative coping } & $1-10$ hours & 110 & 5.0315 & 1.27034 & \multirow{4}{*}{0.592} & \multirow{4}{*}{0.620} \\
\hline & 11-20 hours & 78 & 5.2073 & 1.20161 & & \\
\hline & 21-35 hours & 78 & 5.1993 & 1.27919 & & \\
\hline & 36 hours and more & 72 & 5.0111 & 1.19434 & & \\
\hline \multirow{4}{*}{ Leisure mood enhancement } & 1-10 hours & 110 & 5.1928 & 1.47855 & \multirow{4}{*}{0.922} & \multirow{4}{*}{0.430} \\
\hline & 11-20 hours & 78 & 5.5064 & 1.24966 & & \\
\hline & 21-35 hours & 78 & 5.4404 & 1.40382 & & \\
\hline & 36 hours and more & 72 & 5.3029 & 1.42493 & & \\
\hline \multirow{4}{*}{ Perceived stress } & $1-10$ hours & 110 & 2.2284 & .69678 & \multirow{4}{*}{0.390} & \multirow{4}{*}{0.760} \\
\hline & 11-20 hours & 78 & 2.1556 & .72971 & & \\
\hline & 21-35 hours & 78 & 2.2773 & .71144 & & \\
\hline & 36 hours and more & 72 & 2.2472 & .80000 & & \\
\hline
\end{tabular}

${ }^{*} \mathrm{p}<0.05, * * \mathrm{p}<0.01$. 
Table 5 compares leisure coping strategies and perceived stress level in terms of time spent on leisure activities. The analysis did not show any significant differences between leisure coping strategies and perceived stress level in terms of time spent on leisure activities.

Table 6. Comparison of leisure coping strategies and perceived stress according to leisure participation type

\begin{tabular}{ccccccc}
\hline Leisure coping strategies & Leisure participation type & $\mathrm{n}$ & Mean & $\mathrm{Sd}$ & $\mathrm{t}$ & $\mathrm{p}$ \\
\hline \multirow{2}{*}{ Leisure companionship } & Active & 135 & 5.4757 & .69058 & & \\
& Passive & 203 & 5.1522 & .73596 & 2.127 & $0.034^{*}$ \\
\hline \multirow{2}{*}{ Leisure palliative coping } & Active & 135 & 5.2963 & 1.30963 & \multirow{2}{*}{0.312} & $0.021^{*}$ \\
\hline \multirow{2}{*}{ Leisure mood enhancement } & Passive & 203 & 4.9802 & 1.40753 & & \\
& Active & 135 & 5.6167 & 1.19522 & \multirow{2}{*}{$0.004^{* *}$} \\
\hline \multirow{2}{*}{ Perceived stress } & Passive & 203 & 5.1656 & 1.25383 & .2935 & $0.001^{* *}$ \\
\hline
\end{tabular}

$* \mathrm{p}<0.05, * * \mathrm{p}<0.01$.

The study also examined whether leisure coping strategies and perceived stress levels differ in terms of type of leisure participation. The analysis found significant differences for "leisure companionship" ( $t=2.127, p<0.05)$, "leisure palliative coping" ( $\mathrm{t}=2.312, \mathrm{p}<0.05)$ and "leisure mood enhancement" $(\mathrm{t}=0.2935, \mathrm{p}<0.01)$ dimensions and for perceived stress level $(\mathrm{t}=-3.307, \mathrm{p}<0.01)$. When differences among the groups are examined, it was found that the students who actively participated in leisure have higher mean scores than students who preferred passive participation for "leisure companionship" (X=5.4757), "leisure palliative coping" $(X=5.2963)$ and "leisure mood enhancement" $(X=5.6167)$. As for perceived stress level, the students who prefer passive participation have higher mean score $(\mathrm{X}=2.3323)$.

\section{Discussion}

This study aims to examine the relationship between university students' perceived stress level and leisure coping strategies. It also examines whether perceived stress and strategies differ according to time spent on leisure and type of leisure participation. The results of the analyses show that university students mostly experience moderate and high levels of stress. The study also revealed a negative significant relationship between leisure coping strategies and its study-specific subdimensions. In addition, perceived stress level of participants who prefer passive participation in leisure are significantly different from that of those who prefer active participation. Similarly, it was found that those who prefer active participation in leisure are significantly different in terms of leisure companionship, leisure palliative coping and leisure mood enhancement. The study does not show any significant difference in perceived stress and strategies according to time spent on leisure.

One of the important findings of the study is that university students mostly experience moderate and high levels of stress. A similar finding was obtained in a study which was conducted by Jordan (2014) with university students in order to examine the relationship between leisure, time pressure and stress management. The study reported that majority of university students have moderate level (47.1\%) and high level (34.4\%) of stress. Awadh et al. (2013) found that $64 \%$ of master degree level pharmacy students have high levels of stress. Bhandari (2012), in his study conducted with students in Nepal, found that the participants had low levels of perceived stress. The reason for this finding was reported to be the fact that the study was conducted at the beginning of the semester. Finally, Marshall, Allison, Nykamp, and Lanke (2008), in their study, concluded that $56.9 \%$ of the students felt quite stressed out. The current study contributes to the literature by revealing that university students mostly experience moderate and high levels of stress.

Another significant finding of the study shows that the mean scores of students in leisure palliative coping dimension-a leisure coping strategy-is higher than other dimensions. A similar finding was reported in the study conducted by Altın (2018) with high school students. This reason leading to this conclusion might be that students see leisure activities as a getaway. Moreover, the study contributes to the literature by reporting that students tend to employ leisure palliative coping strategy when they are stressful.

The study also revealed a negative relationship between perceived stress and leisure coping strategies. Accordingly, if students employ leisure coping strategies when stressed out, their stress level will decrease. In other words, participation in leisure activities in order to change emotional state, stay away from stress and stress 
resources and receive social support by meeting with friends will decrease perceived stress level (Iwasaki \& Mannell, 2000). The findings of the study carried out by Kim and Brown (2018) with university students clearly support this finding. Similarly, Reich and Zautra (1981) found a relationship between regular participation in leisure activities and low stress levels, which is consistent with the findings of the current study. According to Kim, Brown, and Yang (2019), participation in leisure activities functions as a buffer against stress. Finally, Jordan (2014) reported a relationship between leisure mood enhancement through leisure activities and low levels of stress, which empirically supports the findings of this study. Thus, the current study contributes to the literature by indicating a negative relationship between perceived stress and leisure coping strategies.

One of the most striking findings of the study is that students with low level of stress are significantly different in terms of leisure companionship and leisure mood enhancement, which are the subdimensions of leisure coping strategies. This finding shows that the university students who participated in the study benefitted from leisure companionship and leisure mood enhancement strategies while coping with stress. The important role of leisure companionship in coping with stress was supported in a study conducted by Soliman (2014) with medicine students. These findings suggest that spending time with friends and family is an important strategy in coping with stress. Jordan (2014), on the other hand, found that students with high levels of perceived stress has high mean scores for leisure mood enhancement dimension, which contradicts with the findings of the current study. Leisure activities is like a buffer against stress since it strengthens social coping strategies by giving people a time-off during stressful moments and helping them develop positive emotions (Coleman \& Iso-Ahola, 1993; Kleiber, Hutchinson, \& Williams, 2002). The study contributes to the literature by providing support for the claim that a leisure activity is a buffer against stress.

The study also examined whether there is a difference between perceived stress level and leisure coping strategies in terms of time spent for leisure; however, the findings did not reveal such a difference. A logical reason for this conclusion might be that students are not aware of the importance of leisure and do not have enough training on leisure. Such training might help students acquire knowledge and skills about leisure, improve their abilities and enjoy their leisure in a creative way (Lyu, Huang, \& Hu, 2019). The current study found that most of the students spend 20 hours or more for leisure activities; however, they experience moderate and high levels of stress. Under the light of this finding, it might be assumed that stress level of people who are aware of the importance of leisure and receive training on leisure might differ according to time spent on this type of activities. However, the study did not reveal such a finding, which might indicate that students lack awareness and training in terms of leisure.

The study also revealed a significant difference between passive and active participants of leisure activities in terms of perceived stress levels. This finding shows that passive participants of leisure have higher levels of stress than active participants do. According to Iwasaki, Mannell, Smale, and Butcher (2005), active leisure plays a significant role in coping with stress and staying healthy. Similarly, Nguyen-Michel, Unger, Hamilton, and Spruijt-Metz (2006) suggest that active leisure is a key coping strategy. In other words, active participation in leisure might decrease stress level, and this finding is consistent with similar findings in the literature. The study contributes to the literature by stating that when students prefer active participation in leisure, their perceived stress might decrease.

In addition to its contribution to the literature, the study provides valuable insights for university administrations. University students have high risk of experiencing stress-related problems because of heavy academic workload, concerns about the future and psychological effects of transition from teenage period to young adulthood. In this group, stress level has negative effects on academic achievement. Moreover, stress might result in malnutrition, overconsumption of alcohol and undesired behaviors and increase anxiety and depression levels, which leads to more frequent visits to healthcare institutions for treatment purposes. In addition, stress increases the risk of chronic diseases (Kim \& Brown, 2018). Both the findings of the current study and other similar studies show that university students have moderate and high levels of stress. Thus, it is necessary to provide university students with opportunities for leisure activities where they can employ leisure coping strategies. Accordingly, it is recommended that university administrations should provide structured leisure activity opportunities for students so that they can avoid stress-related risks and behaviors. The priority should be given to leisure activity experiences and services in various recreation programs through which students might improve their friendships, socialize, receive social support, change their emotional states and avoid stress.

The participants with low levels of perceived stress showed significant differences in leisure coping strategies, which might imply that leisure coping strategies play important roles in coping with stress. Therefore, it is recommended that university administrations should provide opportunities for leisure training sessions to increase students' awareness about leisure and help them discover the functions of leisure activities and how they can benefit from these functions. One opportunity to achieve this purpose might be to integrate leisure training 
programs into curricula because such programs encourage autonomous actions, development of positive identity, sense of belonging and necessary skills (Hartman, Evans, \& Anderson, 2017). By taking such a course, university students might develop their skills regarding leisure coping strategies.

Iwasaki and Mannell (2000) suggest three leisure coping strategies: leisure companionship, leisure palliative coping and leisure mood enhancement. The current study found a negative relationship between perceived stress and leisure coping strategies. Under the light of this finding, it is recommended that university administrations should provide students with opportunities to help them develop awareness about leisure coping strategies and acquire necessary related skills. Campus recreation activities are one of the opportunities that might be used to achieve this purpose. These recreation programs are currently organized under the supervision of Department of Health, Culture and Sports across Turkey. However, it might be more effective if universities establish their own recreation units just like in Canada, the USA and Australia so that they can provide more effective leisure and campus recreation programs for their students. These units can offer leisure programs to help them cope with stress more effectively, to increase their life quality and to enrich their learning experiences.

\section{Limitations and Future Studies}

Several limitations should be taken into account when considering the results of this study. First, the data were collected from the students attending only one university in Turkey, which is a limitation to generalize the findings. The second limitation to generalization of the findings is that the participants were determined by using convenience-sampling method. Therefore, future studies should be conducted with participants to be determined through random sampling method. Secondly, this study is limited to following leisure coping strategies: leisure companionship, leisure palliative coping and leisure mood enhancement. Further studies might identify other leisure coping strategies used by university students and examine their relationships with perceived stress. Thirdly, this study examined the relationship between perceived stress and leisure coping strategies for students at different class levels $\left(1^{\text {st }}, 2^{\text {nd }}, 3^{\text {rd }}\right.$ and $4^{\text {th }}$ year students). It is suggested that future studies might be conducted only with newcomers and fourth year students, who are likely to experience relatively higher levels of perceived stress. Fourthly, the study found that students spend considerable amount of time on leisure; however, there was not any difference in their stress level and this situation was associated with lack of awareness and training. Therefore, future studies might examine stress levels of students who take or do not take leisure training according to time they spent for leisure. Finally, this study was conducted during the spring term. Future studies might be conducted during examination periods when students feel stressed out the most. By doing so, researchers might obtain data regarding which leisure coping strategies they employ during such stressful situations.

\section{References}

Akbaş, S. (2018). University students stress coping styles with their emotional intelligence skills: A reserach at pamukkale university (Unpublished master's thesis). Pamukkale University, Denizli, Turkey.

Altın, M. (2018). Strategies of high school students to cope with stress through leisure time. International Journal of Higher Education, 7(4), 195-202. https://doi.org/10.5430/ijhe.v7n4p195

Anastasiades, M. H., Kapoor, S., Wootten, J., \& Lamis, D. A. (2017). Perceived stress, depressive symptoms, and suicidal ideation in undergraduate women with varying levels of mindfulness. Archives of Women's Mental Health, 20(1), 129-138. https://doi.org/10.1007/s00737-016-0686-5

Avşaroğlu, S., \& Üre, Ö. (2007). Üniversite öğrencilerinin karar vermede özsaygi, karar verme ve stresle başaçikma stillerinin benlik saygisi ve bazi değişkenler açisindan incelenmesi. Selçuk Üniversitesi Sosyal Bilimler Enstitüsü $\quad$ Dergisi, $18, \quad 85-100 . \quad$ Retrieved from http://dergisosyalbil.selcuk.edu.tr/susbed/article/view/439/421

Awadh, A. I., Aziz, N. A., Yaseen, S. N., Abdulameer, S. A., Sahib, M. N., \& Al-Lela, O. Q. B. (2013). A comparison study of perceived stress and quality of life among Master of Pharmacy and non-pharmacy master's students. Pharmacy education, 13(1), 22-28. Retrieved from https://pharmacyeducation.fip.org/pharmacyeducation/article/view/219/192

Aydın, B., \& İmamoğlu, S. (2001). Stresle başa çıkma becerisi geliştirmeye yönelik grup çalışması. Marmara Üniversitesi Atatürk Eğitim Fakültesi Ĕ̈itim Bilimleri Dergisi, 14, 41-52. Retrieved from https://dergipark.org.tr/tr/pub/maruaebd/issue/368/2524

Bhandari, P. (2012). Stress and health related quality of life of Nepalese students studying in South Korea: A cross sectional study. Health and Quality of Life Outcomes, 10(26), 1-9. https://doi.org/10.1186/1477-7525-10-26 
Borjalilu, S., Mohammadi, A., \& Mojtahedzadeh, R. (2015). Sources and severity of perceived stress among Iranian medical students. Iranian Red Crescent Medical Journal, 17(10). https://doi.org/10.5812/ircmj.17767

Browne, M. W., \& Cudeck, R. (1993). Alternative ways of assessing model fit. In K. A. Bollen, \& J. S. Long (Eds.), Testing Structural Equation Models (pp. 136-162). Newbury Park, CA: Sage.

Çakmak, Ö., \& Hevedanlı, M. (2005). Eğitim ve Fen-Edebiyat Fakülteleri Biyoloji Bölümü Öğrencilerinin Kaygı Düzeylerinin Çeşitli Değişkenler Açısından İncelenmesi. Elektronik Sosyal Bilimler Dergisi, 4(14), 115-127. Retrieved from https://dergipark.org.tr/tr/pub/esosder/issue/6128/82187

Carver, C. S., \& Scheier, M. F. (1994). Situational coping and coping dispositions in a stressful transaction. Journal of Personality and Social Psychology, 66(1), 184-195. https://doi.org/10.1037/0022-3514.66.1.184

Cavallo, P., Carpinelli, L., \& Savarese, G. (2016). Perceived stress and bruxism in university students. BMC Research Notes, 9(1), 514. https://doi.org/10.1186/s13104-016-2311-0

Çevik, H., Özcan, Ö., \& Munusturlar, S. (2018). Boş zaman yoluyla stresle baş etme inancı ölçeği ve boş zaman yoluyla stresle baş etme strateji ölçeği'nin faktör yapısının Türkiye örneklemine yönelik sınanması: Geçerlik ve güvenirlik çalışması. Spormetre Beden Eğitimi ve Spor Bilimleri Dergisi, 16(2), 36-50. https://doi.org/10.1501/Sporm_0000000353

Cohen, S., Kamarck, T., \& Mermelstein, R. (1983). A Global Measure of Perceived Stress. Journal of Health and Social Behavior, 24(4). https://doi.org/10.2307/2136404

Coleman, D., \& Iso-Ahola, S. E. (1993). Leisure and health: The role of social support and self-determination. Journal of Leisure Research, 25(2), 111-128. https://doi.org/10.1080/00222216.1993.11969913

Denovan, A., \& Macaskill. A. (2016). Stress and Subjective Well-being among First Year UK Undergraduate Students. Journal of Happiness Studies, 18(2), 505-525. https://doi.org/10.1007/s10902-016-9736-y

Dewe, P., \& Trenberth, L. (2005). An exploration of the role of leisure in coping with work related stress using sequential tree analysis. British Journal of Guidance \& Counselling, 33(1), 101-116. https://doi.org/10.1080/03069880412331335885

Diehr, P. H., Derleth, A. M., McKenna, S. P., Martin, M. L., Bushnell, D. M., Simon, G., \& Patrick D. L. (2006). Synchrony of change in depressive symptoms, health status, and quality of life in persons with clinical depression. Health and Quality of Life Outcomes, 4(27). https://doi.org/10.1186/1477-7525-4-27

Doğan, B., \& Eser, M . (2013). Üniversite öğrencilerinin stresle başa çıkma yöntemleri: Nazilli MYO Örneği. Ejovoc (Electronic Journal of Vocational Colleges), 3(4). Retrieved from https://dergipark.org.tr/en/pub/ejovoc/issue/5389/73083

Eskin, M., Harlak, H., Demirkıran, F., \& Dereboy, Ç. (2013). Algılanan stres ölçeğinin Türkçeye uyarlanması: güvenirlik ve geçerlik analizi. New/Yeni Symposium Journal, 51(3), 132-140. Retrieved from http://yenisymposium.com/Pdf/TR-YeniSempozyum-c1d2631c.PDF

Eskişehir Technical University. (2020). Sayılarla üniversitemiz. Retrieved from https://eskisehir.edu.tr/universitemiz/sayilarla-universitemiz/ogrenci-sayilari/2018-2019/2018-2019-ogretim -yili-mayis-ogrenci-sayilari

Field, A. (2000). Discovering statistics using spss for windows. London-Thousand Oaks-New Delhi: Sage Publications.

Folkman, S., Moskowitz, J. T., Ozer, E. M., \& Park, C. L. (1997). Positive meaningful events and coping in the context of HIV/AIDS. In B. H. Gottlieb (Ed.), Coping with chronic stress (pp. 293-314). New York, NY: Plenum Press. https://doi.org/10.1007/978-1-4757-9862-3_11

Güçlü, N. (2001). Stres yönetimi. Gazi Üniversitesi Gazi Eğitim Fakültesi Dergisi, 21(1), 91-109. Retrieved from http://www.gefad.gazi.edu.tr/tr/issue/6769/91096

Hair, J. F., Black, W. C., Babin, B. J., \& Anderson, R. E. (2014). Multivariate data analysis (7th ed.). Harlow: Pearson Education Limited.

Hartman, C. L., Evans, K. E., \& Anderson, D. M. (2017). Promoting adaptive coping skills and subjective well-being through credit-based leisure education courses. Journal of Student Affairs Research and Practice, 54(3), 303-315. https://doi.org/10.1080/19496591.2017.1331852

Heinen, I., Bullinger, M., \& Kocalevent, R. D. (2017). Perceived stress in first year medical 
students-associations with personal resources and emotional distress. BMC Medical Education, 17(4). https://doi.org/10.1186/s12909-016-0841-8

Hellriege, L. D., Slocum, J. W., \& Woodman, R. W. (1992). Organizational behavior. New York, NY: Western Publishing.

Iwasaki, Y (2003). Examining Rival Models of Leisure Coping Mechanisms. Leisure Sciences, 25(2-3), 183-206, https://doi.org/10.1080/01490400306560

Iwasaki, Y. (2001). Contributions of leisure to coping with daily hassles in university students' lives. Canadian Journal of Behavioural Science/Revue Canadienne des Sciences du Comportement, 33(2), 128-141. https://doi.org/10.1037/h0087135

Iwasaki, Y. (2003). Roles of leisure in coping with stress among university students: A repeated-assessment field study. Anxiety, Stress and Coping: An International Journal, 16, 31-57. https://doi.org/10.1080/1061580021000057022

Iwasaki, Y., \& Mannell, R. C. (2000). Hierarchical dimensions of leisure stress coping. Leisure Sciences, 22(3), 163-181. https://doi.org/10.1080/01490409950121843

Iwasaki, Y., Mannell, R. C., Smale, B. J., \& Butcher, J. (2005). Contributions of leisure participation in predicting stress coping and health among police and emergency response services workers. Journal of Health Psychology, 10(1), 79-99. https://doi.org/10.1177/1359105305048557

Jordan, K. A. (2014). Leisure activity and coping with the stress of university life (Unpublished master's thesis). The University of Georgia. Athens, Georgia.

Joudrey, A. D., \& Wallace, J. E. (2009). Leisure as a coping resource: A test of the job demand-control-support model. Human Relations, 62(2), 195-217. https://doi.org/10.1177/0018726708100357

Kanters, M. A. (2000). Recreational sport participation as a moderator of college stress. Recreational Sports Journal, 24(2), 10-23. https://doi.org/10.1123/nirsa.24.2.10

Kausar, R. (2010). Perceived stress, academic workloads and use of coping strategies by university students. Journal of Behavioural Sciences, 20(1), 31-45. Retrieved from https://scinapse.io/papers/2188512843

Kim, J. H., \& Brown, S. L. (2018). The associations between leisure, stress, and health behavior among university students. American Journal of Health Education, 49(6), 375-383. https://doi.org/10.1080/19325037.2018.1516583

Kim, J. H., Brown, S. L., \& Yang, H. (2019). Types of leisure, leisure motivation, and well-being in university students. World Leisure Journal, 61(1), 43-57. https://doi.org/10.1080/16078055.2018.1545691

Kimball, A., \& Freysinger, V. J. (2003). Leisure, stress, and coping: The sport participation of collegiate student-athletes. Leisure Sciences, 25(2-3), 115-141. https://doi.org/10.1080/01490400306569

Kleiber, D. A., Hutchinson, S. L., \& Williams, R. (2002). Leisure as a resource in transcending negative life events: Self-protection, self-restoration, and personal transformation. Leisure Sciences, 24(2), 219-235. https://doi.org/10.1080/01490400252900167

Kline, R. B. (2011). Principles and practice of structural equation modeling (3rd ed.). New York, NY: Guilford Press.

Lyu, J., Huang, H., \& Hu, L. (2019). Leisure education and social capital: The case of university programmes for older adults in China. Journal of Hospitality, Leisure, Sport \& Tourism Education, 25, 100207. https://doi.org/10.1016/j.jhlste.2019.100207

Marshall, L. L., Allison, A., Nykamp, D., \& Lanke, S. (2008). Perceived stress and quality of life among doctor of pharmacy students. American journal of pharmaceutical education, 72(6). https://doi.org/10.5688/aj7206137

McHugh, R. K., Sugarman, D. E., Meyer, L., Fitzmaurice, G. M., \& Greenfield, S. F. (2020). The relationship between perceived stress and depression in substance use disorder treatment. Drug and Alcohol Dependence, 207, 107819. https://doi.org/10.1016/j.drugalcdep.2019.107819

Nguyen-Michel, S. T., Unger, J. B., Hamilton, J., \& Spruijt-Metz, D. (2006). Associations between physical activity and perceived stress/hassles in college students. Stress and Health, 22(3), 179-188. https://doi.org/10.1002/smi.1094

Patterson, I., \& Coleman, D. (1996). The impact of stress on different leisure dimensions. Journal of Applied 
Recreation $\quad$ Research, 21(3), 243-263. $\quad$ Retrieved from https://www.cabdirect.org/cabdirect/abstract/19981802540

Reich, J. W., \& Zautra, A. (1981). Life events and personal causation: Some relationships with satisfaction and distress. Journal of Personality and Social Psychology, 41(5), 1002-1012. https://doi.org/10.1037/0022-3514.41.5.1002

Saeed, A. A., Bahnassy, A. A., Al-Hamdan, N. A., Almudhaibery, F. S., \& Alyahya, A. Z. (2016). Perceived stress and associated factors among medical students. Journal of family \& community medicine, 23(3), 166. https://doi.org/10.4103/2230-8229.189132Z

Savcı, M., \& Aysan, F. (2014). Üniversite öğrencilerinde algılanan stres düzeyi ile stresle başa çıkma stratejileri arasındaki ilişki. Uluslararası Türk Ĕgitim Bilimleri Dergisi, 3, 44-56. Retrieved from https://dergipark.org.tr/en/pub/goputeb/issue/33496/380060

Şensoy, G., Akiman, H., Balkan, K., Gül, Y. S., Kaval, A., Sevinç, A., ... \& Baş, A. U. (2018). Eğitim Fakültesi Akademisyen ve Öğrencilerinin Üniversite Psikolojik Danışma Birimine Yönelik Görüşleri. Journal of Higher Education \& Science/Yüksekögretim ve Bilim Dergisi, 8(1). https://doi.org/10.5961/jhes.2018.261

Shaikh, B., Kahloon, A., Kazmi, M., Khalid, H., Nawaz, K., Khan, N., \& Khan, S. (2004). Students, stress and coping strategies: a case of Pakistani medical school. Education for Health, 17(3), 346-353. https://doi.org/10.1080/13576280400002585

Şimşek, K. Y., \& Çevik, H. (2020). Development of the Leisure Activity Participation Scale (LAPS). Loisir et Société/Society and Leisure, 1-18. https://doi.org/10.1080/07053436.2020.1727661

Soliman, M. (2014). Perception of stress and coping strategies by medical students at King Saud University, Riyadh, Saudi Arabia. Journal of Taibah University Medical Sciences, 9(1), 30-35. https://doi.org/10.1016/j.jtumed.2013.09.006

Türküm, A. S. (2002). Stresle başa çıkma ölçeğinin geliştirilmesi: geçerlilik ve güvenilirlik çalışmaları. Türk Psikolojik Danışma ve Rehberlik Dergisi, 2(18), 25-34. Retrieved from https://dergipark.org.tr/tr/pub/tpdrd/issue/21438/229810

\section{Copyrights}

Copyright for this article is retained by the author(s), with first publication rights granted to the journal.

This is an open-access article distributed under the terms and conditions of the Creative Commons Attribution license (http://creativecommons.org/licenses/by/4.0/). 